\title{
Grazing behaviour of the giraffe in Hwange National Park, Zimbabwe
}

\author{
P.A. Seeber ${ }^{1 *}$, H.T. Ndlovu ${ }^{2}$, P. Duncan ${ }^{3}$, A. Ganswindt ${ }^{1,4}$ \\ ${ }^{1}$ Department of Production Animal Studies, Faculty of Veterinary Science, University of \\ Pretoria 0002. Postal: Private Bag X04, 0110 Onderstepoort, Pretoria, South Africa. E-mail: \\ paseeber@zoology.up.ac.za Telephone: 0027-73-901448 / 0027-125-29 8143 \\ ${ }^{2}$ Department of Forest Resources \& Wildlife Management, National University of Science and \\ Technology, P.O. Box AC 939 Ascot-Bulawayo, Zimbabwe. E-mail: honesthabss@gmail.com \\ ${ }^{3}$ CNRS Centre d'Études Biologiques de Chizé, 79360 Beauvoir-sur-Niort, France. E-mail: \\ patrick.duncan@cebc.cnrs.fr \\ ${ }^{4}$ Department of Zoology \& Entomology, Mammal Research Institute, University of Pretoria \\ 0002.Postal: Private Bag X04, 0110 Onderstepoort, Pretoria, South Africa. E-mail: \\ aganswindt@zoology.up.ac.za
}

${ }^{*}$ corresponding author: Peter Seeber

\section{Introduction}

The giraffe (Giraffa camelopardalis) is usually described as an exclusive browser, feeding only on shrubs and trees, preferrably between 2 - 5 metres above ground (Ciofolo \& Le Pendu, 2002; Lamprey, 1963; MacNaughton \& Georgiadis, 1986). Although browsing seems to be an easier form of feeding for giraffes in terms of accessibility and vigilance (Young \& Isbell, 1991), a few studies mention that the giraffe also 'very occasionally' feeds on grass (Du Toit, 2005; Pienaar, 1963). To be able to graze, a giraffe has to adopt the typical 'drinking position', where the forelegs are splayed out laterally, and sometimes the carpal joints are also flexed. In this position the animals are particularly vulnerable to predators (Périquet et al., 2010). In this Note, we show that grazing, although not a core activity, is a recurrent event in a nutrient-poor environment such as Hwange National Park, and suggest a possible function. 


\section{Materials and Methods}

Giraffes (Giraffa c. angolensis) were observed in Hwange National Park, Zimbabwe, from March to May 2011. The study area included several water holes and open grasslands in the Main Camp area (Guvalala to Ngweshla Pan). 188 hours of observations were conducted from about 50-100 m distance, and a total of 1107 giraffe sightings were made. Focal observations were made on individuals when they were seen to feed from the herb layer, referred to as grazing. Grazing sites were examined after each observation and only herbaceous plants were found in each case. The local herb layer is dominated by grass, and visual evidence of grazing always accounted for grass, not forbs. We therefore consider that consumption of forbs was insignificant. In most cases of grazing (80\%), the observation commenced an individual was opportunistically found grazing. On only three occasions individuals started to graze during an on-going observation.

Feeding related behaviours (Table 1) were recorded using ad-libitum and alloccurrence sampling (Altmann, 1974). Grazing was recorded only when other similar behaviours like drinking or geophagy could be excluded. All animals that were found grazing (Figure 1) were photographed for identification (Innis, 1958; Dagg, 1971), to allow a comparison of individual frequency and duration. A grazing bout was defined as starting when the giraffe assumed the bent-down position to feed on grass, and ended when it got up again (Figure 1A). The duration of grazing bouts as well as number of bouts per event were recorded. A grazing event started when a giraffe adopted the bent-down position for the first time during an observation and ended when grazing was terminated by shifting to a different behaviour or moving out of sight. For each event, the overall time an individual spent on grazing and directly associated behaviours, e.g. walking between grazing patches or scanning between bouts (Inclusive grazing time), was recorded. In addition, the total time an individual spent ingesting herbaceous plants in a bent-down position with head to the ground was calculated (Exclusive grazing time).

\section{Results \& Discussion}

Grazing behaviour was observed on 31 occasions (27 times by adult/subadult cows, twice by adult males and juveniles, respectively), although typical woody food plants (e.g. species of Acacia, Combretum, Terminalia, Dichrostachys) were in leaf and browsed on during the study period. Grazing was observed for 174 min (exclusive 
grazing time), representing $1.5 \%$ of the total observation time, at seven different locations. For five of these locations, salt licks were found within $20 \mathrm{~m}$ of the grazing patch. A total of 21 grazing giraffes were identified, and three individuals have been repeatedly observed grazing on different days. Grazing individuals were almost exclusively found in groups, consisting of four to sixteen animals and up to four giraffes were seen grazing together. We only observed one case of a solitary individual grazing. In order to feed from the herb layer, the giraffe bends down adopting the drinking position and grazes to the front and to the side as well (Figure 2). Grazing was followed by geophagy twice, within $15 \mathrm{~min}$. To change grazing patches, giraffes usually got up. Only one giraffe was seen to switch the position of one of its forelegs while still bent down, thereby increasing its foraging range. Grazing was frequently interrupted by vigilance (Figure $2 \mathrm{~B}$ ), as seen during browsing and drinking (Cameron \& Du Toit, 2005; Ginnett \& Demment, 1997). Overall grazing times, number of bouts per grazing event, and duration of bouts are summarised in Table 2.

Our results support previous findings that giraffes do feed from the herb layer (Ciofolo \& Le Pendu, 2002; Du Toit, 2005; Pienaar, 1963). However, our short-term study indicates that grazing seems not to be an exceptional event. During our observations the grass layer was already senescent, indicating very low digestible protein/energy content (Safari et al., 2011; Tefera et al., 2009). In contrast, some of the giraffes' preferred browse species reach their maximum protein content during this time (Sauer, 1983). We therefore assume that the function of feeding on herbs during the dry season is not principally to supplement protein/energy intake, but rather to access other nutritional factors not currently present in sufficient amounts in browse, since previous studies imply that the herb layer sometimes has more available micronutrients than browse (Bowell \& Ansah, 1993; Milewski \& Diamond, 2000). Giraffes are likely to require large amounts of minerals (Milewski \& Diamond, 2000; Mitchell \& Skinner, 2003), which is also assumed to be the driving force behind osteophagy (Wyatt, 1971; Kok \& Opperman, 1980). The soil in Hwange consists principally of Kalahari sands, which are extremely poor in nutrients (Childes \& Walker, 1987). Therefore further data on the concentration of micronutrients in the plants eaten would be of great interest to draw conclusions on the functions of grazing in giraffes in Hwange National Park. 


\section{Acknowledgements}

This study was financially supported by the Endocrine Research Laboratory and Faculty of Veterinary Science, University of Pretoria, the Giraffe Conservations Foundation, and the CNRS HERD Programme directed by Hervé Fritz. We are grateful to the Zimbabwe Parks and Wildlife Management Authority for permission to conduct research in Hwange National Park.

\section{References}

ALTMANN, J. (1974) Observational stud of behavior: sampling methods. Behaviour 49, 227-267.

BOWELL, R.J. \& ANSAH, R.K. (1993) Trace element budget in an African savannah ecosystem. Biogeochemistry 20, 103-126.

CAMERON, E.Z. \& DU TOIT, J.T. (2005) Social influences on vigilance behaviour in giraffes, Giraffa camelopardalis. Anim. Behav. 69, 1337-1344.

CHILDES, S.L. \& WALKER, B.H. (1987) Ecology and dynamics of the woody vegetation on the Kalahari Sands in Hwange National Park, Zimbabwe. Vegetatio 72, 111-128.

CIOFOLO, I. \& LE PENDU, Y. (2002) The feeding behaviour of giraffe in Niger. Mammalia 66, 183-194.

DAGG, A. (1971) Giraffa camelopardalis. Mamm. Species 5, 1-8.

DU TOIT, J (2005) Order Ruminantia. In: Mammals of the Southern African Subregion. (Eds. J.D. SKINNER \& C.T. CHIMIMBA). Cambridge University Press, Cambridge.

GINNETT, T.F. \& DEMMENT, M.W. (1997) Sex differences in giraffe foraging behaviour at two spatial scales. Oecologia 110, 291-300.

INNIS, A. (1958) The behaviour of giraffe Giraffa camelopardalis in the eastern Transvaal. Proc. Zool. Soc. Lond. 131, 245-275. 
KOK, O.B. \& OPPERMAN, D.P. (1980) Feeding behaviour of the giraffe Giraffa camelopardalis in the Willem-Pretorius-Game-Reserve, Orange-Free-State. S. Afr. J. Wildl. Res. 10, 45-55.

LAMPREY, H.F. (1963) Ecological separation of the large mammal species in the Tarangire game reserve, Tanganyika. Afr. J. Ecol. 1, 63-92

MCNAUGHTON, S.J. \& GEORGIADIS, N.J. (1986) Ecology of African Grazing and Browsing Mammals. Annu. Rev. Ecol. Syst. 17, 39-65.

MILEWSKI, A. \& DIAMOND, R. (2000) Why are very large herbivores absent from Australia? A new theory of micronutrients. J. Biogeogr. 27, 957-978.

MITCHELL, G. \& SKINNER, J.D. (2003) On the origin, evolution and phylogeny of giraffes Giraffa camelopardalis. Trans. Roy. Soc. S. Afr. 58, 51-73.

PÉRIQUET, S., VALEIX, M., LOVERIDGE, A.J., MADZIKANDA, H., MACDONALD, D.W. \& FRITZ, H. (2010) Individual vigilance of African herbivores while drinking: the role of immediate predation risk and context. Anim. Behav. 79, 665-671.

PIENAAR, U. DE V. (1963) The large mammals of the Kruger National Park - their distribution and present-day status. Koedoe 6, 1-37.

SAFARI, J., MUSHI, D.E., KIFARO, G.C., MTENGA, L.A. \& EIK, L.O. (2011) Seasonal variation in chemical composition of native forages, grazing behaviour and some blood metabolites of small East African goats in a semi-arid area of Tanzania. Anim. Feed. Sci. Technol. 164, 62-70.

SAUER, J. (1983) A comparison between Acacia and Combretum leaves utilized by giraffe. S. Afr. J. Anim. Sci.13, 43-44.

TEFERA, S., MLAMBO, V., DLAMINI, A.M., KORALAGAMA, K.D. \& MOULD, F.L. (2009) Chemical composition and in vitro ruminal fermentation of selected grasses in the semiarid savannas of Swaziland. Afr. J. Range Forage Sci. 26, 9-17.

WYATT, J.R. (1971) Osteophagia in Masai giraffe. East Afr. Wildl. J. 9, 157.

YOUNG, T.P. \& ISBELL, L.A. (1991) Sex differences in giraffe feeding ecology: energetic and social constraints. Ethology 87, 79-89. 
Table 1. Ethogram of feeding and associated behaviours in giraffes observed in Hwange National Park, Zimbabwe.

\begin{tabular}{ll} 
Behaviour & Description \\
\hline graze & 'drinking position' adopted by splaying its legs out laterally, in \\
& some cases also bending the carpal joints, and lowering the head \\
& to the ground, where the giraffe ingests herbaceous plants. Head \\
& and neck moves from one side to the other. \\
\hline drink & 'drinking position' adopted by splaying its legs out laterally and \\
& bending carpal joints, lowering the head to reach a ground-level \\
& water source. If the water source cannot be seen from a distance, \\
& drinking can be confirmed when the giraffe raises its head and \\
& water is dripping out of its mouth. Head and neck is kept in a \\
& steady position. \\
\hline geophagy & 'drinking position' adopted by splaying its legs out laterally, in \\
& some cases also bending the carpal joints, the head is lowered to \\
& ground level to ingest soil by licking the ground or biting the soil. \\
the giraffe stands in an upright position and forages on trees or \\
shrubs, the neck may be bent down, but legs are not spread apart \\
or bent.
\end{tabular}


Table 2. Distribution and length of grazing events observed in giraffe at Hwange National Park, Zimbabwe.

\begin{tabular}{lllll}
\hline & $\begin{array}{l}\text { Time }_{\text {incl }}{ }^{\mathrm{a}} \\
(\mathrm{min})\end{array}$ & $\begin{array}{l}\text { Time }_{\text {excl }} \\
(\mathrm{min})\end{array}$ & Count of bends & Duration of bout (s) \\
\hline mean $\pm \mathrm{sd}$ & $20 \pm 11$ & $5 \pm 4$ & $13 \pm 9$ & $23 \pm 10$ \\
\hline min-max & $4-42$ & $1-18$ & $2-36$ & $4-49$ \\
\hline
\end{tabular}

${ }^{a}$ Inclusive grazing time: amount of time spent on grazing and directly associated behaviour (walking between grazing patches and scanning between grazing bouts). ${ }^{\mathrm{b}}$ Exclusive grazing time: amount of time spent on ingesting grass in a bent-down position with head to the ground. 


\section{Figure legend}

Figure 1: Grazing giraffe in typical position legs splayed out laterally, but carpal joints not bent. A: Sequence of grazing $(A 1 ; 3)$ interrupted by scanning (A2). B: close-up showing grass in the mouth. Photo: P. Seeber, Hwange National Park. 
Figure 1.
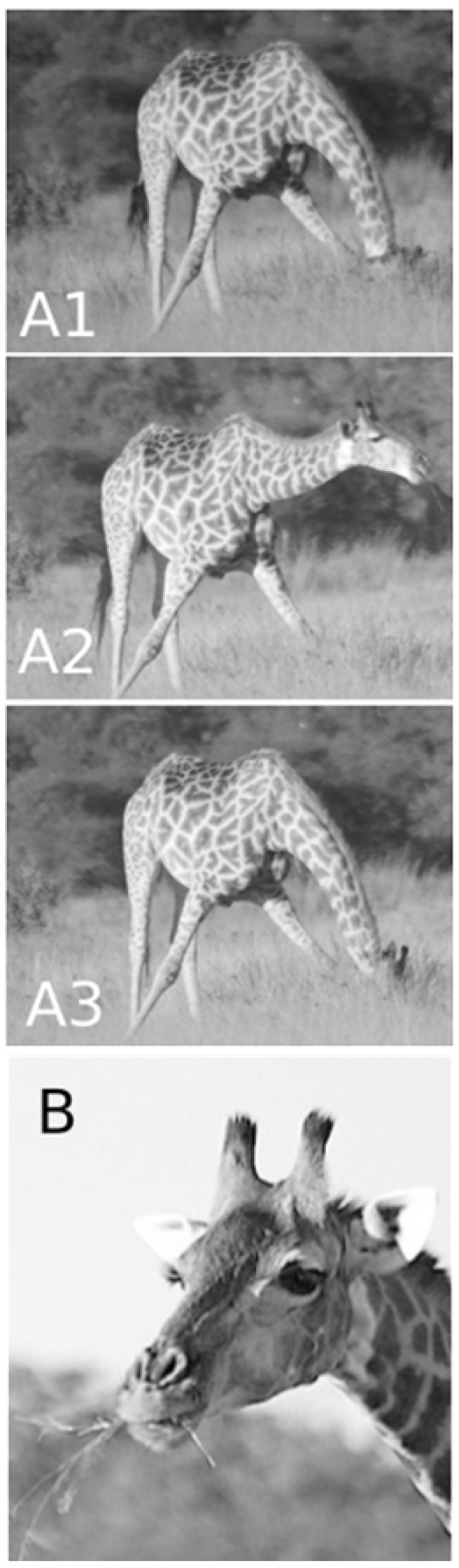